\title{
The Use of Drama in English Language Teaching
}

Paul Davies

$\begin{array}{ll}\begin{array}{l}\text { This essay aims to examine the use of } \\ \text { drama and dramatic activities in English }\end{array} & \begin{array}{l}\text { needs, how to present and integrate drama } \\ \text { into the lesson, and overall classroom }\end{array} \\ \text { Language Teaching (ELT). Its opening } & \text { organization. The next section tackles the } \\ \text { part looks at some of the theories behind } & \text { question of how dramatic activities can be } \\ \text { the use of drama with learners of English, } & \text { employed in the language classroom. The } \\ \text { and tries to answer questions such as what } & \text { possibilities considered include mime, } \\ \text { is drama, who needs it, and when should } & \text { simulation, role-play, scripted plays, } \\ \text { it be used. The essay then takes a look at } & \text { improvisation, and coursebook dialogue. } \\ \text { some practical procedural strategies such } & \text { Some concluding remarks finish off the } \\ \text { as lesson preparation, students' language } & \text { main body of the essay. }\end{array}$

There are a number of ways in which drama can be defined. It could be seen as a blanket term covering "a wide range of oral activities that have an element of creativity present" (Hubbard et al 1986: 317). Susan Holden takes drama to mean any kind of activity where learners are asked either to portray themselves or to portray someone else in an imaginary situation: "In other words, drama is concerned with the world of 'let's pretend'; it asks the learner to project himself imaginatively into another situation, outside the classroom, or into the skin and persona of another person" (Holden 1982: 1). The students may do this on their own or with one or more fellow students; they may act either in a controlled way in accordance with organizational and linguistic guidelines established by the teacher, or they may be left fairly free to work matters out. In both cases the students interact with other people and react to what they do and say, making use of their own personal store of language in order to communicate in a meaningful manner.

Alan Maley and Alan Duff make the point that dramatic activities are not the performance of plays before passive audiences; the value of these activities lies "not in what they lead up to but in what they are, in what they bring out right now" (Maley and Duff 1984: 6). This comment can be interpreted as meaning that students do their 'acting' for language and imaginative activity, and not for exhibition. Nevertheless, teachers should not deny their students the opportunity to act out their scenes to the rest of the class if they so wish, for if rehearsed drama activities are left unperformed, there may be a sense of incompleteness in the class. 
In more specific, concrete terms, drama includes mime, role-playing, extended role-playing (or improvisation), simulation, interaction activities such as various forms of dialogues, and dramatized story-telling.

So drama can take several forms in the language classroom, but above all it should be a communicative activity where the student makes the choices.

\section{Who needs drama?}

As long as the teacher knows the class well and has a good relationship with it, all ages and levels of ability should be able to profit from involvement in drama provided they are well prepared and confident in their work. If the teachers know their classes well, they will be able to recognize any social or religious taboos the group may have and therefore be careful about asking all members of the class to do everything. An atmosphere must be established in which both teacher and class can feel secure in the knowledge and expectation that they will enjoy and benefit from drama activities.

\section{When should drama be used?}

Drama activities could probably be used in any or all stages of the typical five-stage lesson to take the focus away from the teacher and put it on the students to give them the maximum amount of talking time. Drama could be particularly effective in stages two to five of a lesson, above all in the fifth stage.

In stage two-the Presentation Stage-a new item of language could be presented by means of a dramatized dialogue on video or audio cassette, as silent reading, or as reading while listening to the teacher or to an audio cassette. This can be done in a regular classroom setting before any sort of area for acting has been created. In the third stage-the Practice Stagethe new vocabulary, structures, or lexis to be learnt can be practised by means of connecting exercises. The students match new vocabulary items on the left hand side of the page with their definitions on the right hand side. New structures or lexis could be practised through connecting or information-gap exercises, and True/False exercises could test listening comprehension. Pair and group role-play exercises using picture or written cues could then follow from this, and the aim is for the learners to infer a rule or pattern from these activities practised under controlled conditions. In the fourth or Further Practice Stage, new situations and different cues are employed to put the recently learnt language items into a new context. Substitution tables asking students to complete gaps with appropriate content and language offer the possibility of making creative use of expressions the learners practised in stage three. In addition, dialogues could be role-played by groups consisting of different members. 
In the final fifth or Free Stage, the teacher usually tries to create conditions in which the new language items can be used freely by the students experimenting with the language they have learnt. Students may organize and act out a scenario in groups centred around the new language. If the class had just been learning how to ask for information in stages one to four of the lesson, one possible way of practising this would be a role-play activity similar to the one suggested by John Dougill (Dougill 1987: 6061): the class is divided into two groups, A and B. Group A is sent outside the room, where its members are told by the teacher that they are all strangers in town wanting to find out where the bus station is, how long it takes to get there, and when the next bus to London is. Group B is then told that its members are in their home town waiting for a bus at a bus stop and that they are hard of hearing. Group B spreads itself out around the class imagining it is waiting for a bus. Before bringing in Group A, the teacher tells its members they are walking down a street when they see someone waiting at a bus stop to whom their questions should be directed. The two groups pair off and interact, and the teacher finally compares what happened in various pairs. This activity, which should last about ten minutes, draws upon three of the elements of drama, namely "the presence of conflict, the imitation of reality, and the practice of improvisation" (Dougill 1987: 60). Purpose and tension is also supplied by employing an objective the other participants do not know about, "a common technique in drama exercises (and plays)" (Dougill 1987: 61).

\section{Some practical procedural strategies}

Like all language activities, drama must be well prepared and conceived before the lesson gets underway. The teachers have to decide why they intend to use dramatic activities with any particular class in order to be able to justify the decisions taken. Some reasons for using drama could be its relevance to the syllabus, the chance to increase awareness of paralinguistic features, linguistic accessibility, intrinsic interest, practicability in terms of lesson time, student numbers and space, and the possibility of using dramatic activities in the future, thereby providing continuity.

The teachers ought to have a clear idea of what they want to achieve in both general and specific terms. The teacher must therefore ask what the students will need to do in the language to successfully carry out the activity, ask if the students know any of the phrases they are likely to need to express these functions, and ask which functions will be called upon (on this point cf. also Maley and Duff 1984: 24).

\section{Presentation and integration of drama}

Susan Holden suggests the following five-point plan for integrating drama activities into the lesson (Holden 1982: 14). First of all, the teacher 
presents the idea, theme, or problem to the students, organizing any preliminary work and making sure that the students know precisely what to do. Then the students discuss in groups what they are going to do and exactly how they are going to do this. Thirdly, the students experiment in groups with various interpretations until they are satisfied with one. A possible fourth stage would consist of students showing their interpretation or solution to another group or to the rest of the class. Finally-or even in place of the fourth stage-the students may discuss their solution in groups or with the rest of the class. This discussion can serve as a form of assessment for the students of their work.

The discussion following dramatic activities makes learners feel that the scene upon which they have just been working has had a satisfactory conclusion with all loose ends being tied up. The discussion should be structured and centred on what happened and why, and it should also address the question as to what the individual student would have done in a similar situation. The motivation to participate in such discussions will depend upon whether they can be made relevant to the interests and potential problems of the class, and upon whether these discussions can provide a meaningful context for real conversation in English. Discussion sessions could be chaired either by the teacher and the whole class, or conducted in groups under the guidance of a nominated group leader, which would certainly increase the amount of individual student talking time.

\section{How can drama or dramatic activities be used in ELT?}

\section{Mime}

John Dougill defines mime as "a non-verbal representation of an idea or story through gesture, bodily movement and expression" (Dougill 1987: 13). Mime emphasizes the paralinguistic features of communication. It builds up the confidence of learners by encouraging them to get up and do things in front of one another. Mime helps develop students' powers of imagination and observation, and can also be quite simply "a source of great enjoyment", with students tending "to be very enthusiastic about this aspect of drama" (Hayes 1984: 28).

Mime is a great way of reinforcing memory by means of visual association, and recall of language items is assisted whenever an associated image is present (cf. Rose 1985: 62). Mime can help to fix language in the minds of the students, and the following activity demonstrates how vocabulary items can be revised and reinforced (cf. Dougill 1987: 15). Placing a box in front of the class, the teacher mimes taking something out of it and asks students to take a guess at what it could be. The teacher then invites a student to approach the box and whispers the name of the object to the student, who in turn mimes taking the object out of the box 
while the rest of the class guesses. This activity may continue with other students miming until the list of words is finished.

It may seem strange to advocate mime as an aid to language teaching when it does not actually use language. Yet mime can generate language use where explanation is required-teacher's instructions and the discussion of the students-if the mime involves pair-work or group work. Learners normally find it easier and more motivating to produce language when they have to accomplish a task (cf. Ur 1981: 3). If the mime is then performed before the rest of the class, the target language can be usefully employed for evaluating and interpreting what has been seen, as in the next example which aims at practising fluency (cf. Dougill 1987: 15-16). Working in pairs or small groups, students are given topics to work on which are to form the basis of a three-minute mime (a burglary that goes wrong, an incident at a bus stop, an argument at the cinema, for example). Five minutes are allowed for preparing and rehearsing, students perform their mimes in turn, and after each performance the teacher asks the class to interpret what it has seen.

\section{Simulation}

A simulation activity is one where the learners discuss a problem (or perhaps a series of related problems) within a defined setting. In simulation activities, the students are either playing themselves or someone else. Simulation activities are also interaction activities with various categories of dialogues. One category would be social formulas and dialogues such as greetings, partings, introductions, compliments, and complaints. Simulation exercises can teach students how to function in a social situation with the appropriate social niceties; for example, students could practise how to turn down a request for a date. Even if the students do not use the accepted convention of making up an excuse like "I'm sorry, but I'm doing something else", it is important that they are aware of these conventions. Another category of simulated interaction activity is community oriented tasks, where students learn how to deal with organizations like the DHSS and how to cope with shopping, buying a ticket at the railway station etc. This sort of simulation helps students' communicative participation in the community and at the very least helps them in the task of collecting important information.

In fact, any kind of problem-solving activity where permission is asked for and given and where problems are negotiated and solved can form the basis of a simulation exercise. The following is a good example (cf. Byrne 1986: 125-28).

A social club is in financial difficulties, and a decision has to be made on whether or not to close it down. A meeting is to be held to try and solve the problem. 
First of all, the setting could be established by providing background information in the form of texts to be read or listened to on the community, the club and its problems. Then the role of the participants can be defined, with some students performing official roles like chairman or club secretary, but the majority playing themselves as members of the public or of the club. The students split up into small groups or pairs to study the background information in detail and prepare for the simulation exercise. The class could at some stage work in three groups: 1) the committee of the club; 2) the members of the public; 3) those students taking the listening roles of reporters whose job it will be to take notes with which to write reports and articles at a later date. All three groups would share any additional information before doing the simulation in about one class period. Follow-up to this simulation could consist of feedback, project work (an actual visit to a social club), and further simulations. ${ }^{1}$

\section{Role-Play}

Role-play normally involves students playing imaginary people in an imaginary situation. Byrne describes some of the ways of providing a framework for the practice of role-play (Byrne 1986: 119-22). Open-ended dialogues provide a frame for starting the role-play, with students free to decide how to develop the dialogues further. Mapped dialogues give students a sort of chart telling them which functions they must use when they are interacting. By having the 'functional' cues for each speaker on separate cards, an information gap is created. The following example concerns two friends:

\section{A}

1) Invite $B$ to go out with you

2) Suggest another possibility

3) Confirm arrangements
$\underline{B}$

1) Decline

2) Accept

3) Agree

Role instructions describe a situation and tell the participants how to interact. The next example contains the key element of unpredictability, a feature of genuine language discourse. The purpose here is to practise inviting and responding to invitations (cf. Dougill 1987: 18-19). A is told to call $B$ to invite $B$ to the cinema tonight. A is also told on the same card that before he or she rings up, A must decide on the choice of film. B is then told on a separate card that he or she has nothing to do tonight; however, B only wants to go to the cinema if the film is the one B would like to see, and this is the element of unpredictability.

Scenarios outline the sequence of events without giving any of the words used. The events could be presented through a series of pictures; the main point is that they should be concerned with realistic everyday 
situations, such as a scene in a restaurant or cafe. With this type of roleplaying, the students, working in groups, will have to decide when the appropriate moment is to talk, whether or not to modify the scenario, whether to work out what they think was actually said, and how they are going to do the role-play. In addition, the students will need to decide about the characters-who they are exactly, what they look like, where they are going-and have a clear idea about the setting (cf. Byrne 1986: 120-22).

\section{Exploiting a scripted play}

In choosing a script, the teacher should ensure that the language is accessible to the learners and relevant to their needs and that the topic arouses the students' interest. Themes relating to family situations are therefore useful, whereas love scenes and nostalgic situations normally are not. Plays such as D.H. Lawrence's The Daughter-In-Law (dialects), N.F. Simpson's The Resounding Tinkle (absurdist humor for teenagers), Alan Ayckbourn's Relatively Speaking (clear and natural if somewhat middleclass dialogue and ordinary English) and Absent Friends (though the themes here are a little more challenging, i.e. death, grief, and social embarrassment), even Eugene Ionesco's The Bald Prima Donna (a parody of the meaningless non-communicative language found in phrase books) would all provide good material for a drama class at intermediate or advanced level in particular. Plays have been written specifcally for English language students, for example A Morning in London by Donn Byrne (1972), which concerns an American tourist's search for his lost passport in places like a police station and a lost property office. All the scenes are very short, and involve no more than 2-3 characters, who are themselves clearly defined as is the locale of each scene.

In order to extract the most out of a play, work on it should be approached in stages. There are various ways of doing this, but the following suggested procedures appear to be the most efficient (cf. Byrne 1986: 124-25).

The students are asked to familiarize themselves with the text by reading it through on their own before listening to a recording of it. The teacher then discusses the text with the class before assigning the roles. The text is played a second time, with the teacher pausing to draw attention to or invite comments on particular utterances, attitudes, or emotions. Dividing the class into groups, the teacher asks the students to discuss the setting and characters in detail. The penultimate stage-probably in a later lesson-has the students in their groups choosing their roles and rehearsing the play (any type of rehearsal is ideal for mastering intonation patterns on account of the repetition involved). The final stage would be the perfor- 
mance of the play or a scene/scenes from it. The performance could be recorded for the students to listen to later. In any case, the performance should be discussed after it is over.

\section{Creating one's own script}

An English language class could, of course, write its own script. Suzanne Hayes puts forward a method of doing so for what she calls post-elementary ESL/EFL students with some previous drama experience. Such a project is supposed to take about six two-hour sessions to complete (cf. Hayes 1984: 98-101).

The teacher and class choose a situation which can be interpreted dramatically with a lot of interaction between students, for example the casualty department of a hospital late at night. The right scene is set by describing and discussing a casualty department, and roles devised by either the teacher or the students themselves. The roles are then typed onto cards and allocated. Students are then asked to study and prepare for their roles so that they can identify with the personalities behind the roles and move towards characterization.

In the next phase, students are directed through an improvisation. All characters are brought in front of the receptionist one by one, scenes of interaction are created between waiting patients, and all characters are brought in one by one before the doctor and nurse. After this improvised session, the action is carefully plotted, shaped, and edited with the teacher and his or her class. Once the structure has been agreed, the play can be properly scripted by the teacher or by the class. After the first reading of the completed script, the play can be staged, and at this point another group discussion would help to consider ways of developing character. As soon as the students are familiar with their roles and the play's action, they can start to learn the words, and the play can be rehearsed until the performance stage is reached, always provided that everyone involved really wants to perform to an audience.

\section{Improvisation without a script}

Improvisation is really a play without a script. Due to this lack of script, there is no dependency upon reading or memory skills, and different levels of language students should be able to take part in it and enjoy it. Thoughts, feelings, and the language arising from them are emphasized in improvisation, and learners create people and relationships by acting out situations using speech and movement, but without a preconceived plan.

There are two main types of improvisation. The first is spontaneous improvisation, an open-ended process initiated by the teacher to help his 
or her class discover the meaning behind language and behaviour. Learners are presented with a situation and challenged to respond to it. The teacher introduces the situation and attempts to create a drama in which all the students can become involved and can willingly suspend their disbelief. The teacher could simply start talking to the class, for example, about three items on the agenda for the evening, namely garbage cans, service charges, and pets on the estate. The teacher finds a volunteer to take the minutes, and then asks the class if anyone would like to say something about the recent complaints as to garbage cans not being emptied. By now the students should have realized that some sort of residents' meeting on a housing estate is being improvised, and they should start to participate (cf. Hayes 1984: 91). Spontaneous improvisation gives learners practice in language and communication skills, and they have the opportunity to develop their emotional range by playing roles unfamiliar to them and outside their own experience.

The second type of improvisation is prepared improvisation, where a class makes up a complete play starting from a basic theme or situation, and during the improvisation the class should develop its ideas, selecting, shaping, and organizing them into a communicative structure. Having chosen a theme, its implications should be discussed, preparation undertaken in small groups, and presentation done to the whole class once the small groups are satisfied with their 'play'. This type of group-prepared improvisation gives students practice in working together, sharing ideas and decision-making, and organizing dramatic statements.

\section{Exploiting the coursebook for dramatic purposes}

In dramatizing textbook dialogues, some students may have difficulty in relating the words in the book to real people in real-life situations. Nevertheless, if teachers manage to use coursebook dialogues to their full potential, they can offer controlled language practice and enliven the language structure or function which is the basis for the lesson.

Coursebook dialogues may be shortened and simplified and then presented in skeletal form on written cue cards for the individual student to make use of. One student is then given part A to act out, another student part B. Parallel scenes that differ just marginally from the textbook can be conceived for purposes of further practice, and learners may then continue and develop the given dialogues with their own language. Such dramatic techniques help bridge the gap between such coursebook dialogues and natural usage.

A lot of modern language textbooks have characters linked to a storyline with recognizable characterstics and personalities. Because the character is so to speak already there and invented, students merely need to produce 
suitable language for the character. The teacher can ask his or her learners to role-play the various characters when they are taking part in a discussion, considering how the character would have regarded the problem being debated and taking decisions based on their knowledge of the character. This can result in a variety of language registers being employed in a natural way.

\section{Further Possibilities}

Drama and language games can serve as a natural introduction to dramatic activities proper and as preparation for role-play, improvisation, and other drama experiences. Because they involve concentration, listening, memorization, observation, interaction, and interpretation, language games extend the word power of learners, and increases their agility, fluency, and flexibility in the use of English. The following types of games could be effectively used at the start of a lesson using drama: name games, yes/no games, "Just a Minute", word association, "What's my occupation?" and of course charades.

Other dramatic activities that could be used in the English language classroom include the community happening, a good way of teaching beginners and children and of involving the audience in the activities of songs, plays, painting, making things, and playing games. If the class has mixed cultural backgrounds, the final quarter of an hour of the lesson could be profitably spent getting the students to talk about their different backgrounds in a sort of dramatized story-telling.

Finally, there are always puppets: the teacher could either use hand-puppets, card-puppets, or even his or her hands and paint them into a puppet. The main point here is to bring in a variety of techniques so that the students do not get bored.

\section{Conclusion: Why use drama, and what are its advantages in ELT?}

Drama bridges the gap between course-book dialogues and natural usage, and can also help to bridge a similar gap between the classroom and real-life situations by providing insights into how to handle tricky situations. Drama strengthens the bond between thought and expression in language, provides practice of supra-segmentals and para-language, and offers good listening practice. If drama is considered as a teaching method in the sense of being part of the eclectic approach to language teaching, then it can become a main aid in the acquisition of communicative competence. Drama activities facilitate the type of language behaviour that should lead to fluency, and if it is accepted that the learners want to learn a language in order to make themselves understood in the target language, then drama does indeed further this end. In addition, drama could always 
be extended and used as a starting-point for other activities. The theme can act as a stimulus for discussion or written work going far beyond the acting out of scenes. Dramatic activities can thus be integrated into a course, which in turn could lead to them being exploited in terms of the language syllabus, for example the learning of vocabulary, even of structures. As matters stand now, drama and dramatic activities tend not to exist as a special area within the syllabus separate from all other language activities, but they often overlap with them.

Perhaps one of the greatest advantages to be gained from the use of drama is that students become more confident in their use of English by experiencing the language in operation. The student-centredness inherent in all dramatic activities also improves students' maturity and motivation, and the physical involvement contained in drama along with the concept of learning language through action is an effective variation on the method of Total Physical Response ${ }^{2}$ and other holistic approaches to language teaching, where the learner rather than the language or indeed the teacher is at the centre of the learning process.

Drama in the English language classroom is ultimately indispensable because it gives learners the chance to use their own personalities. It draws upon students' natural abilities to imitate and express themselves, and if well-handled should arouse interest and imagination. Drama encourages adaptability, fluency, and communicative competence. It puts language into context, and by giving learners experience of success in real-life situations it should arm them with confidence for tackling the world outside the classroom.

\section{APPENDIX}

The following is a list of appropriate plays teachers and students could use as part of drama and dramatic activities in English Language teaching:

John Osborne, Look Back in Anger.

Agatha Christie, The Mousetrap and Ten Little Indians.

J. B. Priestley, An Inspector Calls.

D. H. Lawrence, The Daughter-In-Law.

N. F. Simpson, The Resounding Tinkle.

Alan Ayckbourn, Relatively Speaking and Absent Friends.

Thornton Wilder, Our Town and The Skin of Our Teeth.

Eugene Ionesco, The Bald Prima Donna.

George Bernard Shaw, Arms and the Man and Pygmalion.

Harold Pinter, A Night Out.

Arnold Wesker, Chicken Soup with Barley.

One-act and shorter plays would also provide a rich source of vocabulary and expressions, and on account of their length and tendency to concentrate on one theme, setting, or idea, they could quite easily be used with less advanced students. Good collections of such plays are to be found in: 
Seven One Act Plays, edited by W. F. Sherwood. House of Grant (Canada) Ltd, 1964.

Best Short Plays of the World Theatre 1958-1967, edited with introductions and prefaces to the plays by Stanley Richards. Crown: New York, 1968. Plays by amongst others Noël Coward, Jean Anouilh, Max Frisch, David Mercer, Sean O'Casey, Luigi Pirandello, John Osborne, Peter Shaffer, and Peter Weiss.

Thirty Famous One Act Plays, edited by Bennett Cerf and Van H. Cartmell. Garden City: New York, 1943. Plays by Anatole France, August Strindberg, Oscar Wilde, John Galsworthy, Anton Chekov, James Barrie, Eugene O'Neill, and Arthur Schnitzler amongst others.

The Best Short Plays: 1989, edited and introduced by Ramon Delgano. Applause Theatre Books: New York, 1989. A series which started back in the 1950s, selecting the best ten to twelve short plays of the current year. An ideal source for those teachers who like to keep abreast of the very latest theatrical developments.

Dramatized fairy-tales and children's plays would be an excellent way of introducing drama to students at an early stage of learning English. An obvious choice would be James Barrie's Peter Pan; or, The Boy Who Would Not Grow Up, and the following collections of plays for children and young people should also be taken into consideration:

Twenty Plays for Young People, selection and foreword by William B. Birner. Anchorage: Kentucky, 1967.

Three Short Plays, presented by Richard Hendry. Heinemann: London, 1979.

Six Plays for Children, variously adapted, dramatized, and written by Aurand Harris. University of Texas Press: Austin, 1977.

Donn Byrne's A Morning in London was quoted in this article as an example of a play written expressly for students of the English language. Teachers may like to consult Off Stage: Sketches from the English Teaching Theatre, Teachers' Book (Heinemann: London, 1981), a selection of fifteen sketches about two or three pages long on average. The sketches practise specific language points and are accompanied by role-playing and improvisation activities as well as by exercises testing listening and reading comprehension. The sketches were originally written for the English Teaching Theatre group, a company founded in 1969 at International House in London with the aim of providing a theatre for English language students. John McRae's Using Drama in the Classroom (Pergamon: Oxford, 1985) offers ten short scenes from plays by Edward Bond, Samuel Beckett, Harold Pinter, Douglas Jerrold, Agatha Christie, Arthur Miller, Oscar Wilde, Alan Ayckbourn, and Arnold Wesker with detailed suggestions for classroom use and exploitation.

\section{NOTES}

1. There are quite obvious elements of role-play in this exercise, and Dougill admits that the differences between simulation and role-playing "are far from clear and the terms have been interpreted in various ways by various authors" (Dougill 1987: 20). C. 
Livingstone even states that in terms of language teaching, the difference between role-play and simulation are unimportant (cf. Livingston 1983: 1).

2. As developed in particular by $J$. Asher in his Learning Another Language Through Actions (1982).

\section{REFERENCES}

Asher, J. J. (1982) Learning Another Language Through Actions. Sky Oaks Productions.

Byrne, Donn. (1986) Teaching Oral English. New Edition: Longman.

Dougill, John. (1987) Drama Activities for Language Learners. Essential Language Teaching Series.

Hayes, Suzanne Karbowska, (1984) Drama As a Second Language: A Practical Handbook for Language Teachers. National Extension College.

Holden, Susan. (1982) Drama in Language Teaching. Longman.

Hubbard, Peter, et al. (1986) A Training Course for TEFL. Oxford University Press.

Livingston, C. (1983) Role Play in Language Learning. Longman.

Maley, Alan, and Alan Duff. (1984) Drama Techniques in Language Learning: A Resource Book of Communication Activities for Language Teachers. Cambridge.

Rose, C. (1985) Accelerated Learning. Topaz.

Ur, P. (1981) Discussions That Work. Cambridge.

\section{THE AUTHOR}

Dr. Paul Davies is Professor of German at Dalhousie University, Halifax, Nova Scotia, Canada, where he also works as a teacher of English as a Foreign Language at the International Language Institute. He graduated with a BA Hons. in German from Leicester University in 1980, and obtained an MA (1981) and PhD (1986) from Manitoba and Queen's University in Canada respectively. In 1987 he received a Certificate in TESOL from Sheffield Polytechnic. He worked for three years as an English teacher in Munich, West Germany, and has taught German at Canadian universities. He has published articles on German literature. 